\title{
Psychometric properties of the SV-RES Resilience Scale in Mexican women with breast cancer
}

\author{
Sol Durand-Arias, ${ }^{,}$Daniel Roldán-Hinojosa, ${ }^{2}$ Ricardo Orozco, ${ }^{3}$ Jazmín Mora-Ríos ${ }^{3}$
}

1 Dirección General, Instituto Nacional de Psiquiatría Ramón de la Fuente Muñiz, Ciudad de México, México.

2 Dirección de Servicios Clínicos, Instituto Nacional de Psiquiatría Ramón de la Fuente Muñiz, Ciudad de México, México.

3 Dirección de Investigaciones Epidemiológicas y Psicosociales, Instituto Nacional de Psiquiatría Ramón de la Fuente Muñiz, México.

Correspondence:

Sol Durand-Arias

Instituto Nacional de Psiquiatría

Ramón de la Fuente Muñiz.

Calz. México-Xochimilco No. 101,

San Lorenzo Huipulco,

14370, Alcaldía de Tlalpan,

Ciudad de México, México.

Phone: 5062 - 1600, Ext. 2480

Email: dra.durand@gmail.com

Received: 4 September 2019 Accepted: 5 December 2019

Citation:

Durand-Arias, S., Roldán-Hinojosa, D. Orozco, R., \& Mora-Ríos, J. (2020) Psychometric properties of the SV-RES Resilience Scale in Mexican women with breast cancer. Salud Mental, 43(2), 92-99.

DOI: $10.17711 /$ SM.0185-3325.2020.013

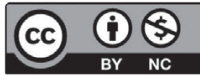

\begin{abstract}
Introduction. Resilience is an adaptation resource for coping with adversity or high risk, in this case, breast cancer diagnosis. The SV-RES Resilience Scale, created in Chile, is a valid, reliable measure for evaluating healthy behaviors in adversity and could be useful for evaluating resources available to women with breast cancer diagnosis in Mexico. Objective. To obtain the psychometric properties of the SV-RES Resilience Scale in Mexican women with breast cancer. Method. 114 women with breast cancer attending a cancer care center were included. They answered the self-administered SV-RES Resilience Scale comprising three resources: "I am," "I have," and "I can." The dimensions of the scale were identified through an exploratory factor analysis. Results. The scale presented overall internal consistency (Cronbach's alpha of .974), with seven dimensions (identity, satisfaction, links, networks, internal strength, self-efficacy, and affectivity/ reciprocity) that accounted for $72.75 \%$ of the variance. Discussion and conclusion. The SV-RES scale is a valid, reliable measure for assessing resilience in Mexican women with breast cancer. Since it is a short, self-administered, and reliable instrument, it is useful for clinical practice and research in similar populations to identify the resources people have for coping with their medical conditions.
\end{abstract}

Keywords: Psychometric validation, resilience, breast cancer, SV-RES Scale, women with breast cancer.

\section{RESUMEN}

Introducción. La resiliencia es un recurso con que cuentan las personas para afrontar situaciones de adversidad o de alto riesgo en su salud, en este caso, el diagnóstico de cáncer de mama. La Escala de Resiliencia SV-RES fue creada en Chile y constituye una medición válida y confiable para evaluar las conductas saludables en condiciones de adversidad y podría ser útil para evaluar los recursos con que cuentan las mujeres mexicanas con diagnóstico de cáncer de mama. Objetivo. Obtener las propiedades psicométricas de la Escala de Resiliencia SV-RES en mujeres mexicanas con cáncer de mama. Método. Participaron 114 mujeres con cáncer de mama que acudieron a un centro especializado en atención oncológica, quienes respondieron la Escala Autoaplicable de Resiliencia SV-RES, que consta de tres recursos "Yo soy / Yo estoy"; "Yo tengo" y "Yo puedo". Las dimensiones de la escala fueron identificadas por medio de un análisis factorial exploratorio. Resultados. La escala presentó una consistencia global interna (alpha de Cronbach de .974), cuyas siete dimensiones (identidad, satisfacción, vínculos, redes, fortaleza interna, autoeficacia y afectividad/reciprocidad) explicaron en conjunto el $72.75 \%$ de la varianza. Discusión y conclusión. La escala SV-RES es una medida válida y confiable para evaluar la resiliencia en mujeres con cáncer de mama. Al ser un instrumento breve, autoaplicable y confiable, constituye un instrumento útil para su aplicación en la práctica clínica y en la investigación en poblaciones similares, con el fin de identificar los recursos con que cuenta la población para enfrentar sus padecimientos.

Palabras clave: Validación psicométrica, resiliencia, cáncer de mama, escala SV-RES, mujeres con cáncer de mama. 


\section{INTRODUCTION}

Having any type of cancer involves the possibility of death, accompanied by pain, loss of independence, and decreased self-esteem (Rouhani \& Holland, 2003). Breast cancer is the most common oncologic pathology in women worldwide, with over two million diagnoses estimated in 2018, accounting for $11.6 \%$ of all cancers. In Mexico, the incidence of breast cancer in women has increased in recent decades, and in 2018 it ranked first with $26 \%$, followed by thyroid cancer with $9.7 \%$, and cervical cancer with $7.5 \%$ (GLOBOCAN, 2019).

A person's ability to cope with a cancer diagnosis and treatment varies according to the evolution of the disease and depends on medical, psychological, and social factors such as medical care, the characteristics of the disease (clinical evolution, site of onset, type of treatment), previous level of adaptation to the condition, prognosis of the disease, management of losses suffered in one's lifetime, emotional support, personality traits, coping mechanisms, cultural, spiritual, and religious environment, and the possibility of physical and psychological rehabilitation (Massie \& Greenberg, 2019).

According to Saavedra and Villalta (2008a), resilience proposes an explanatory hypothesis of healthy behavior in adverse or high-risk conditions. It is a personal trait, constituted on the basis of the early bond and cultivated throughout the history of the subjects, enabling them to appropriate life events. For Rutter (2012), resilience can be defined as a reduced vulnerability to risk experiences, overcoming a stressor or adversity, or a relatively good outcome despite experiences of risk. It is therefore an interactive concept in which the presence of resilience must be deduced from individual variations in the outcomes of those who have experienced a significant stressor or adversity.

It is currently thought that resilience also plays an important role in the experience of adverse or traumatic events, such as disease process. The work of Grotberg (2003) in The International Resilience Project 2003-2005 proposed a resilience model based on the possession of three resources expressed as follows: "I am," "I have," and "I can." Although Grotberg states that, for her conceptualization of resilience, not all the resources mentioned are required, the presence of only one of them does not suffice: in other words, resilience is the result of the combination of these three resources. These resources provide an idea of how the subject appropriates reality and opens up the possibility of a healthy behavior or overcoming traumatic events.

Based on the above, Saavedra and Villalta (2008a) take up the notion of the resources raised by Grotberg (2003) and add the history of the subject, on the assumption that the way each person interprets and acts in the face of problems recurs throughout their lifetime. Accordingly, for these authors, a resilient response is an action characterized by an evaluation of the cognitive and affective elements of the problem that arise from a system of beliefs and social ties that provide security. These authors created a resilience scale, which proved to be valid and reliable for the Chilean general population (Saavedra \& Villalta, 2008b).

The interest in studying these issues stems from a repeated observation in clinical practice: women who seek oncology services - regardless of their economic, social or environmental conditions - react to and cope with the diagnosis in very different ways, which, in some cases leads to the presence of depression and/or anxiety. But what are the individual differences that lead women with breast cancer to produce maladaptive psychological responses that can lead to the development of a psychiatric diagnosis? One possible answer is resilience, which has been studied in a medically ill population because the loss of physical health is considered an adverse event in life related to psychological processes. Previous studies in other countries (Alcalde, Alcalde, \& Palacios Banchero, 2011; Becoña Iglesias, 2006; Benvenuto Haase, 2015; Moscoso-Escalante \& Castañeda-Chang, 2018; Retiz Flores, 2016) show that valid, and reliable resilience measurements do exist. One of the main strengths of the SV-RES scale is that it addresses the different components of resilience, rather than adopting a one-dimensional perspective, as has traditionally been the case in studies with medically ill populations using the Resilience Scale created by Connor-Davidson (CD-RISC; Connor \& Davidson, 2003; Markovitz, Schrooten, Arntz, \& Peters, 2015; Matzka et al., 2016; Min et al., 2013; Sharpley, Bitsika, Wootten, \& Christie, 2014).

Although the SV-RES scale was created and validated in a Spanish-speaking and Latin American population, it is necessary to evaluate its psychometric characteristics to determine whether it is useful for the sample in this study and could therefore be included in the broader research of which it formed part. In this respect, Reyes-Lagunes (2011) states that when a scale has been designed in a different cultural environment, it is essential to know its structure in the new context. The objective of the present study is therefore to appreciate the different components of resilience proposed through the SV-RES Scale in a sample of Mexican women with breast cancer diagnosis.

\section{METHOD}

\section{Study design}

Cross-sectional, non-probabilistic study.

\section{Participants}

A sample of 114 women with breast cancer attending a specialized cancer center in the south of Mexico City was studied. The study was reviewed and approved by the 
ethics committee of the Instituto Nacional de Psiquiatría Ramón de la Fuente Muñiz (CEI/C/021/2015). The women were invited to voluntarily collaborate in the study. Those who agreed signed an informed consent form prior to their participation.

Participants were recruited by the principal investigator during the first clinical psychiatric evaluation and selected on the basis of the following inclusion criteria: patients with breast cancer in outpatient treatment, who were undergoing any form of cancer treatment (surgery, chemotherapy, or radiotherapy), were at any stage of the cancer process, and could read and write. Exclusion criteria included the presence of comorbid neoplasia or clinically evaluated cognitive impairment. Patients who met the inclusion criteria were invited to participate voluntarily and told the objective of the research. They were informed that their participation was independent of the care they received at the center, and that they would be able to leave the study at any time.

The procedure used to calculate the sample size was contrasting proportions (with an alpha level of $5 \%$ and statistical power of $80 \%$ ), since validation of the scale was part of a broader research project in which the relationship between resilience and depression and anxiety was studied. This sample size is suitable for factor analysis (Brown, 2015), and was calculated using Stata 13.1 (StataCorp, 2014).

\section{Measurements}

Resilience Scale (SV-RES). This scale was developed by Saavedra and Villalta in Chile and is a Latin American resilience measurement alternative designed to answer two questions: "What personal resources does the subject use to cope with adversity in a conscious, intentional way?" and "How is resilient behavior constituted from the perspective of the subject?" (Saavedra \& Villalta, 2008a).

It is a self-applicable scale with 60 items divided into three resources "I am," "I have," and "I can," which in turn form 12 specific resilience factors: identity, autonomy, satisfaction, pragmatism, links, networks, models, goals, affectivity, self-efficacy, learning, and generativity. The questionnaire has Likert-type response options, ranging from 1 - "strongly disagree" to 5 - "strongly agree," yielding a minimum score of 60 and a maximum of 300 for the total scale. The highest score reflects greater skills or resilient characteristics. The validity study carried out by the authors showed a concurrent $r=.76$ and reliability measured through the Cronbach's alpha of .96 (Saavedra \& Villalta, 2008a).

For the purposes of this research, prior to the application of the scale, the cultural relevance of the contents of the instrument was analyzed, on an item-by-item basis, through an invitation to participate in two focus groups: one with five experts on oncology and another comprising ten women with breast cancer. Based on the observations made by the participants of both groups, some adjustments were made to clarify the contents of the items. Among the changes made, clearer, more precise language was used for women. For example, item 16, "I am a practical person" was modified to "I am a person with practical tools;" item 19 was modified from "I constantly review the meaning of my life;" to "I regularly analyze the meaning of my life;" and item 26 was modified from "I have access to social-public services" to "I have access to public community centers."

\section{Procedure}

Eligible women candidates were identified and given the self-applicable questionnaire. Care was taken to ensure that the respondents understood the questions properly. The sociodemographic and clinical data of each participant were recorded in a database specifically designed for this purpose.

\section{Statistical analysis}

First, the sociodemographic and clinical characteristics of the study sample were reported through central tendency and dispersion measures for quantitative variables, as well as percentages for qualitative variables.

Second, the factor structure of the items was analyzed through a Exploratory Factor Analysis (Tabachnick \& Fidell, 2013), using the main components method for extracting and estimating the parameters (factor loads and variances). The advantage of the principal component method is that it does not impose restrictions on the distribution of the parameters and is robust to violations of multivariate normality (Fabrigar, Wegener, MacCallum, \& Strahan, 1999). The promax oblique rotation method was used rather than orthogonal rotation, since it provides a more realistic representation of the relationship between the factors (Brown, 2015). The factor structure was separately explored for each theoretical resource presented, and an exploratory factor analysis was undertaken of items 1-20 for the "I am" resource; from 2140 for the "I have" resource, and from 41-60 for the "I can" resource. In factors with eigenvalues greater than 1 , the factor loads of the items were identified, which were considered if they exceeded the .35 value and its theoretical content. Cronbach's alpha (Streiner \& Norman, 1995) was calculated as an indicator of internal consistency.

Statistical analyses were performed using SPSS software (version 21) (IBM Corporation, 2012).

\section{RESULTS}

A total of 114 women diagnosed with breast cancer were included. The average age was 54.42 years, with an age range of 33-94 ( $S D 10.14$ years). The average number of years of schooling of the sample was 8.44 ( $S D 3.78$ years). Over a 
Table 1

Factors and items in the SV-RES Scale obtained through factor analysis

Items

Factor load

"I am" resource

Factor 1: Identity

1. I am a hopeful person $\quad .716$

2. I am a person with good self-esteem $\quad .542$

3. I am optimistic about the future $\quad .462$

$\begin{array}{ll}\text { 4. I am sure of my beliefs and principles } & .724\end{array}$

5. I am growing as a person $\quad .448$

6. I am surrounded by people who help me in difficult situations $\quad 390$

7. I am in touch with people who appreciate me $\quad .473$

8. I am sure of myself $\quad .752$

11. I am a person who has learned to get ahead in life 739

17. I am a person with goals in life $\quad .529$

18. I take an active approach to my problems $\quad .880$

19. I constantly review the meaning of my life $\quad .526$

20. I find solutions to my problems $\quad .721$

Cronbach's alpha $=.907$

Factor 2: Satisfaction

9. I am sure of my projects and goals $\quad .545$

10. I am confident in the setting I live in $\quad .455$

13. I am well integrated into the place where I work or study .631

14. I am satisfied with my friendships $\quad .765$

15. I am satisfied with my affective relations $\quad .831$

Cronbach's alpha $=.819$

"I have" resource

Factor 3: Links

21. I have reliable personal relations $\quad .368$

23. I have solid affective relations $\quad .426$

31. I have people who have given me guidance and advice $\quad 664$

32. I have people who help me avoid dangers or problems $\quad .855$

33. I have people I can trust $\quad .860$

34. I have people who have confided their problems in me 697

35. I have people who have accompanied me when I have had problems $\quad .756$

38. I have people with whom I can cope with problems 582

Cronbach's alpha $=.878$

Factor 4: Networks

22. I have a well-structured family $\quad .567$

26. I have access to public social services $\quad .591$

27. I have people who support me $\quad .872$

28. I have people I can turn to if I have problems 891

29. I have people who encourage my autonomy and initiative $\quad .514$

Cronbach's alpha $=.819$

Factor 5: Internal strength

24. I have internal strength $\quad .784$

25. I have a meaningful life $\quad .721$

36. I have short-term goals $\quad .662$

37. I have clear objectives $\quad .708$

39. I have future projects $\quad .835$

40. I have problems I can solve $\quad .813$

Cronbach's alpha $=.891$ 


\begin{tabular}{|c|c|}
\hline Items & Factor load \\
\hline \multicolumn{2}{|l|}{ "I can" resource } \\
\hline \multicolumn{2}{|l|}{ Factor 6: Self-efficacy } \\
\hline 44. I can overcome the difficulties that arise in life & .573 \\
\hline 50. I can assume responsibility for what I do & .778 \\
\hline 51. I can be creative & .629 \\
\hline 52. I can communicate properly & .640 \\
\hline 53. I can learn from my successes and mistakes & .551 \\
\hline 55. I can make decisions & .417 \\
\hline 56. I can create strategies to solve my problems & .757 \\
\hline 57. I can set realistic goals & .790 \\
\hline 58. I can strive to achieve my objectives & .701 \\
\hline 59. I can assume risks & .830 \\
\hline 60. I can see myself in the future & .874 \\
\hline \multicolumn{2}{|l|}{ Cronbach's alpha $=.919$} \\
\hline \multicolumn{2}{|l|}{ Factor 7: Affectivity/reciprocity } \\
\hline 41. I can talk about my emotions & 677 \\
\hline 42. I can express affection & .918 \\
\hline 43. I can trust people & 647 \\
\hline 45. I can form affective bonds & .893 \\
\hline 46. I can solve problems effectively & .653 \\
\hline 47. I can give my opinion & .730 \\
\hline 48. I can seek help when I need it & .725 \\
\hline 49. I can support others who have difficulties & .483 \\
\hline 54. I can collaborate with others to improve life in the community & .651 \\
\hline \multicolumn{2}{|l|}{ Cronbach's alpha $=.907$} \\
\hline \multicolumn{2}{|l|}{ Cronbach's alpha total scale $=.974$} \\
\hline \multicolumn{2}{|l|}{ Items eliminated } \\
\hline \multicolumn{2}{|l|}{ 12. I am a positive model for other people } \\
\hline \multicolumn{2}{|l|}{ 16. I am a practical person } \\
\hline 30. I am satisfied with what I have achieved in life & \\
\hline
\end{tabular}

Table 2

Self-values, explained variance and correlations between factors, by resource

\begin{tabular}{lcccc}
\hline & Total self-value & \% of variance & Accumulated \% & $\begin{array}{c}\text { Correlation } \\
\text { between factors }\end{array}$ \\
\hline "I am" resource & & & & \\
$\quad$ Factor 1: Identity & 8.2 & 45.8 & 45.8 & .547 \\
Factor 2: Satisfaction & 1.2 & 6.8 & 52.5 & \\
"I have" resource & & & & \\
Factor 3: Bonds & 8.4 & 44.2 & 44.2 & $.409^{\text {a }}$ \\
Factor 4: Networks & 1.7 & 9.2 & 53.4 & $.391^{\text {b }}$ \\
Factor 5: Internal strength & 1.5 & 8.1 & 61.5 & $.510^{c}$ \\
"I can" resource & & & & \\
Factor 6: Self-efficacy & 10.0 & 49.9 & 49.9 & .630 \\
Factor 7: Affectivity/reciprocity & 1.6 & 8.1 & 58.0 & \\
\hline
\end{tabular}

a Correlation of bonds and networks.

b Correlation of networks and internal strength.

c Correlation of bonds and internal strength. 
third of the women $(36.9 \%)$ had some type of occupation involving financial remuneration, whether self-employment, part-time, or full-time, work.

Regarding the clinical variables, 56\% were at an early clinical stage (in-situ cancer until clinical stage IIA) and, at the time of the evaluation, were undergoing chemotherapy-based treatment $(81.6 \%)$ or surgery $(69.3 \%)$.

\section{Factor structure}

Factor analysis of the resilience scale was carried out using the method of extracting principal components through oblique rotation. See, Table 1 below for the items comprising each of the three resources with their respective factor loads and internal consistencies.

For the "I am" resource, two factors were found which together accounted for $52.52 \%$ of the variance (Table 2). Because two items loaded on both factors, it was decided to eliminate them (items 12 and 16). Factor 1 was called "Identity," while factor 2 was called "Satisfaction."

For the "I have" resource, three factors were identified that explained $61.54 \%$ of the variance; item 30 was eliminated because it loaded on all three factors. Factor 3 was called "Bonds," factor 4 was termed "Networks," and factor 5 was designated "Internal strength."

Lastly, for the "I can" resource, two factors were found that together accounted for $57.97 \%$ of the variance, without eliminating any items. Factor 6 was called "Self-efficacy," while factor 7 was termed "Affectivity/reciprocity."

The total scale -with 57 items and seven factors- had high overall internal consistency (Cronbach's alpha of .97) and accounted for $72.75 \%$ of variance. It is worth mentioning that although some of the factors identified coincide with those proposed by the authors of the scale, there were others that are not the same and were entitled "Internal strenght" and "Affectivity/reciprocity." Finally, the descriptive statistics of the scores by factor are shown in Table 3.

Table 3

Descriptive statistics of total scores of each factor, by resource

Mean SD Minimum Maximum

\begin{tabular}{lllll}
\hline "I am" resource & & & & \\
$\quad$ Factor 1: Identity & 57.8 & 5.9 & 37 & 65 \\
$\quad$ Factor 2: Satisfaction & 21.8 & 2.6 & 13 & 25 \\
“I have" resource & & & & \\
$\quad$ Factor 3: Links & 35.4 & 3.8 & 25 & 40 \\
Factor 4: Networks & 21.8 & 2.8 & 12 & 25 \\
Factor 5: Internal strenght & 25.4 & 3.4 & 15 & 30 \\
“I can" resource & & & & \\
Factor 6: Self-efficacy & 47.5 & 5.4 & 32 & 55 \\
Factor 7: Affectivity/reciprocity & 38.3 & 4.7 & 25 & 45 \\
\hline
\end{tabular}

Note: SD = Standard desviation.

\section{DISCUSSION AND CONCLUSION}

The SV-RES scale is a valid, reliable instrument for assessing resilience in Mexican women with breast cancer. The overall internal consistency obtained was extremely adequate (Cronbach's alpha $=.97$ ) and coincides with that reported by the authors of the original instrument (Cronbach's alpha $=.96$ ) (Saavedra and Villalta, 2008a), and is similar to that obtained by Lerma et al. (2019) in Mexican patients with chronic renal failure undergoing hemodialysis (Cronbach's alpha $=.96$ ) and higher than that reported in the Mexican Resilience Scale $($ Cronbach's alpha $=.93)($ Camacho Valadez, 2016).

The factor structure obtained in this study was different from the original proposal, with seven factors being obtained instead of the 12 identified by the authors, which jointly explained $72.7 \%$ of the variance. These differences may be due to sociodemographic factors. For example, the original validation was carried out in the general population (men and women) aged between 15 and 65, whereas our sample consisted solely of women with oncologic pathology. We also consider that the grouping of items into certain factors may be related to their cultural understanding; for example, item 17: "I am a person with goals in life," which was originally located within the "Pragmatism" factor is grouped under the "Identity" category here.

The most consistent items were those related to problem solving, emotional ties and future projection. These results were consistent with similar research on breast cancer patients. For example, Ocampo et al. (2011) showed a positive, significant correlation between breast cancer patients and the dimensions of social support, strength, meaning of life, and identity. There is also evidence to suggest that individuals with greater resilience have certain characteristics such as adequate reality checks, greater tolerance of negative emotions, a strong capacity for self-reflection, and a great sense of responsibility (Vanderpol, 2002), essential to understanding the emotional response to the disease and its treatments.

As a self-applicable instrument with adequate reliability for clinical practice and research on the oncological population, it is useful for determining the psychological resources women have such as resilience.

A limitation of the present study is that the cultural adaptation of the items in the SV-RES scale was not carried out in the general Mexican population, but with two focus groups: one with experts in oncology and the other comprising women with breast cancer. Another limitation is related to the selection of participants, which was based on a non-probabilistic sample of women attending a specialized care center in the south of Mexico City. Lastly, although the sample obtained was enough to conduct the exploratory analysis, it was not possible to obtain the confirmatory analysis due to the limitations indicated by the Green (1991) model, which remains pending for future research. 
These findings should be viewed with caution before extrapolating them to all Mexican women with breast cancer. However, educational attainment and the proportion of women with paid work in our study sample are similar to that of the national population (42.2\%) (Instituto Nacional de Estadística Geografía e Informática [INEGI], 2019; Organización Internacional del Trabajo, 2014; Secretaría del Trabajo y Previsión Social, 2019).

Regarding future implications for resilience research, it is essential to identify the factors that will make it possible to homologate its conceptual definition and standardize evaluation measures - even longitudinally. Likewise, it is necessary to promote research on resilience and its impact on the health-disease process, as well as the development of care programs that promote resilience as a means of contributing to a more comprehensive management of medical conditions, to improve well-being and quality of life for all individuals.

This is important when considering the clinical implications in which, through a greater knowledge of psychological processes in this group of patients, care programs that promote positive psychology can be implemented -with special emphasis on resilience- to reduce the emotional burden and psychiatric diagnoses and thereby improve the quality of life in women with breast cancer.

\section{Financing}

None.

\section{Conflicts of interest}

The authors declare they have no conflicts of interest.

\section{Acknowledgements}

This study was undertaken as part of the Master's and Doctoral Programs in Medical and Dental Sciences of the Universidad Nacional Autónoma de México (UNAM) with the support of a Master's degree grant from the Consejo Nacional de Ciencia y Tecnología (CONACYT).

\section{REFERENCES}

Alcalde, Á., Alcalde, M. J., \& Palacios Banchero, A. (2011). Trauma resiliencia: niños con experiencia de vida en la calle. Athenea, 2(2), 47-79. Retrieved from http://www.academiaperuanadepsicologia.net/atenea/Atenea\%2002.pdf

Becoña Iglesias, E. (2006). Resiliencia: definición, características y utilidad del concepto. Revista de Psicopatologia y Psicologia Clinica, 11(3), 125-146. doi: 10.5944/rppc.vol.11.num.3.2006.4024

Benvenuto Haase, I. F. (2015). Resiliencia en madres adolescentes institucionalizadas en dos programadas de acogida. (Tesis - Licenciatura en Psicología Clínica). Universidad Peruana de Ciencias Aplicadas, Lima, Peru.

Brown, T. A. (2015). Confirmatory factor analysis for applied research. USA, New York: Guilford press. ISBN 9781462515363

Camacho Valadez, D. (2016). Propiedades psicométricas de la escala de resiliencia mexicana en población del norte de México. Enseñanza e Investigación en Psicologia, 21(1), 78-83. Retrieved from https://www.redalyc.org/ pdf/292/29248180009.pdf

Connor, K. M., \& Davidson, J. R. (2003). Development of a new resilience scale: The Connor-Davidson Resilience Scale (CD-RISC). Depression and Anxiety, 18(2), 76-82. doi: $10.1002 /$ da. 10113
Fabrigar, L. R., Wegener, D. T., MacCallum, R. C., \& Strahan, E. J. (1999). Evaluating the use of exploratory factor analysis in psychological research. Psychological Methods, 4(3), 272-299. doi: 10.1037/1082-989X.4.3.272

GLOBOCAN. (May, 2019). Mexico. Retrieved from https://gco.iarc.fr/today/data/ factsheets/populations/484-mexico-fact-sheets.pdf

Green, S. B. (1991). How many subjects does it take to do a regression analysis? Multivariate Behavioral Research, 26(3). 499-510. doi: 10.1207/ s15327906mbr2603_7

Grotberg, E. (2003). Nuevas tendencias en resiliencia: Resiliencia, descubrimientos de las propias fortalezas. Spain: Paidós.

IBM Corporation. (2012). IBM SPSS Statistics for Windows. Version 21.0. Armonk, NY: IBM Corp.

Instituto Nacional de Estadística Geografía e Informática (INEGI). (2019). Retrieved from https://www.inegi.org.mx

Lerma, A., Ordónez, G., Mendoza, L., Salazar-Robles, E., Rivero, J., Pérez-Granados E., ... Lerma, C. (2019). Psychometric properties of the resilience scale in Mexican patients with chronic hemodialysis. Salud Mental, 42(3), 121-129. doi: 10.17711/SM.0185-3325.2019.016

Markovitz, S. E., Schrooten, W., Arntz, A., \& Peters, M. L. (2015). Resilience as a predictor for emotional response to the diagnosis and surgery in breast cancer patients. Psycho-Oncology, 24(12), 1639-1645. doi:10.1002/pon.3834

Massie, M., \& Greenberg, D. (2019). Oncology. In J. Levenson (3rd Edition), Textbook of psychosomatic medicine and consultation psychiatry (pp. 871-917). Barcelona: Ars Médica.

Matzka, M., Mayer, H., Köck-Hódi, S., Moses-Passini, C., Dubey, C., Jahn, P., ... Eicher, M. (2016). Relationship between resilience, psychological distress and physical activity in cancer patients: A cross-sectional observation study. PloS One, 11(4), e0154496. doi: 10.1371/journal.pone.0154496

Min, J. A., Yoon, S., Lee, C. U., Chae, J. H., Lee, C., Song, K. Y., \& Kim, T. S. (2013). Psychological resilience contributes to low emotional distress in cancer patients. Supportive Care in Cancer, 21(9), 2469-2476. doi: 10.1007/s00520-013-1807-6

Moscoso-Escalante, S. J., \& Castañeda-Chang, A. M. (2018). Validez y confiabilidad de la Escala de Resiliencia (SV-RES) para adultos mayores en Lima metropolitana. Búsqueda, 5(21), 165-181. doi: 10.21892/01239813.419

Ocampo, J., Valdez-Medina, J. L., González-Arratia, N. I., Andrade-Palos, P., OblitasGuadalupe, L. A., \& García-Fabela, R. O. (2011). Variables Psicológicas Predictoras de la Calidad de Vida en Pacientes con Cáncer de Mama. Revista Argentina de Clínica Psicológica, 20(3), 265-269. Retrieved from https://www. redalyc.org/pdf/2819/281922826009.pdf

Organización Internacional del Trabajo. (2014). Panorama Laboral 2014. América Latina y el Caribe. Lima: Oficina Regional de la OIT para América Latina y el Caribe.

Retiz Flores, O. (2016). Resiliencia, bienestar y expresión artística en jóvenes en situación de pobreza. (BSc in Psychology). Tesis Licenciatura en Psicología. Lima, Peru: Pontificia Universidad Católica del Perú. Retrieved from http:// tesis.pucp.edu.pe/repositorio/handle/20.500.12404/7312

Reyes-Lagunes, I. (2011). Conceptualización y desarrollo de la etnopsicometría en México. In Domínguez Espinoza, A. (Comp.). Letras Introductorias a la Psicología cultural, transcultural y etnopsicología (pp. 279-302). Mexico City: Universidad Iberoamericana.

Rouhani, M., \& Holland, J. (2003). Aspectos psiquiátricos del cáncer. In M. Gelder (Ed.). Tratado de Psiquiatría (pp. 1407-1415). Madrid, Spain: Ars Médica.

Rutter, M. (2012). Resilience as a dynamic concept. Development and Psychopathology, 24(2), 335-344. doi: 10.1017/S0954579412000028

Saavedra, E., \& Villalta, M. (2008a). Escala de Resiliencia SV-RES, para jóvenes y adultos. Santiago, Chile: Centro de Estudios y Atención del Niño y la Mujer (CEANIM).

Saavedra, E., \& Villalta, M. (2008b). Medición de las características resilientes, un estudio comparativo en personas entre 15 y 65 años. Liberabit, 14(14), 32-40.

Secretaría del Trabajo y Previsión Social. (2019). Retrieved from https://www.gob.mx/ stps/

Sharpley, C. F., Bitsika, V., Wootten, A. C., \& Christie, D. R. H. (2014). Does resilience 'buffer' against depression in prostate cancer patients? A multi-site replication study. European Journal of Cancer Care, 23(4), 545-552. doi: 10.1111/ecc.12170

StataCorp. (2014). Stata Statistical Software. Version 13.1. College Station, TX: StataCorp LP.

Streiner, D. L., \& Norman, G. R. (1995). Health Measurement Scales. A practical guide to their development and use (2nd Edition). New York: Oxford University Press.

Tabachnick, B. G., \& Fidell, L. S. (2013). Using multivariate statistics (6th Edition), Boston, MA: Pearson Education Limited.

Vanderpol, M. (2002). Resilience: A missing link in our understanding of survival. Harvard Review of Psychiatry, 10(5), 302-306. doi: 10.1080/10673220216282 
APPENDIX

Escala de Resiliencia SV-RES

Evalúe el grado en que estas afirmaciones la describen.

Marque con una " $X$ " su respuesta. Conteste todas las afirmaciones. No hay respuestas buenas ni malas.

\begin{tabular}{|c|c|c|c|c|c|c|}
\hline & & $\begin{array}{c}\text { Muy } \\
\text { de acuerdo }\end{array}$ & De acuerdo & $\begin{array}{l}\text { Ni de acuerdo } \\
\text { ni desacuerdo }\end{array}$ & $\begin{array}{c}\text { En } \\
\text { desacuerdo }\end{array}$ & $\begin{array}{c}\text { Muy en } \\
\text { desacuerdo }\end{array}$ \\
\hline \multicolumn{7}{|c|}{ Yo soy - Yo estoy } \\
\hline 1. & Una persona con esperanza & & & & & \\
\hline 2. & Una persona con buena autoestima & & & & & \\
\hline 3. & Optimista respecto del futuro & & & & & \\
\hline 4. & Segura de mis creencias o principios & & & & & \\
\hline 5. & Creciendo como persona & & & & & \\
\hline 6. & $\begin{array}{l}\text { Rodeada de personas que en general me ayudan } \\
\text { en situaciones difíciles }\end{array}$ & & & & & \\
\hline 7. & En contacto con personas que me aprecian & & & & & \\
\hline 8. & Segura de mi misma & & & & & \\
\hline 9. & Segura de mis proyectos y metas & & & & & \\
\hline 10. & Segura en el ambiente en que vivo & & & & & \\
\hline 11. & $\begin{array}{l}\text { Una persona que ha aprendido a salir adelante } \\
\text { en la vida }\end{array}$ & & & & & \\
\hline 12. & Un modelo positivo para otras personas & & & & & \\
\hline 13. & Bien integrada en mi lugar de trabajo, estudio o & & & & & \\
\hline 14 & Satisfecha con mis relaciones de amistad & & & & & \\
\hline 15. & Satisfecha con mis relaciones afectivas & & & & & \\
\hline 16. & Una persona con herramientas prácticas & & & & & \\
\hline 17. & Una persona con metas en la vida & & & & & \\
\hline 18. & Activa frente a mis problemas & & & & & \\
\hline 19. & Analizo de manera regular el sentido de mi vida & & & & & \\
\hline 20. & Generando soluciones a mis problemas & & & & & \\
\hline \multicolumn{7}{|c|}{ Yo tengo } \\
\hline 21. & Relaciones personales confiables & & & & & \\
\hline 22. & Una familia bien estructurada & & & & & \\
\hline 23. & Relaciones afectivas sólidas & & & & & \\
\hline 24. & Fortaleza interior & & & & & \\
\hline 25. & Una vida con sentido & & & & & \\
\hline 26. & Acceso a centros comunitarios públicos & & & & & \\
\hline 27. & Personas que me apoyan & & & & & \\
\hline 28. & A quien recurrir en caso de problemas & & & & & \\
\hline 29. & Personas que estimulan mi autonomía e iniciativa & & & & & \\
\hline 30. & Satisfacción con lo que he logrado en la vida & & & & & \\
\hline 31. & Personas que me han orientado y aconsejado & & & & & \\
\hline 32. & $\begin{array}{l}\text { Personas que me ayudan a evitar peligros } 0 \\
\text { problemas }\end{array}$ & & & & & \\
\hline 33. & Personas en las cuales puedo confiar & & & & & \\
\hline 34. & Personas que han confiado sus problemas en mi & & & & & \\
\hline 35 & $\begin{array}{l}\text { Personas que me han acompañado cuando he } \\
\text { tenido problemas }\end{array}$ & & & & & \\
\hline 36. & Metas a corto plazo & & & & & \\
\hline 37. & Mis objetivos claros & & & & & \\
\hline 38. & Personas con quien enfrentar los problemas & & & & & \\
\hline 39. & Proyectos a futuro & & & & & \\
\hline 40. & Problemas que puedo solucionar & & & & & \\
\hline
\end{tabular}




\section{Appendix (continued)}

\begin{tabular}{|c|c|c|c|c|c|c|}
\hline & & $\begin{array}{c}\text { Muy } \\
\text { de acuerdo }\end{array}$ & De acuerdo & $\begin{array}{l}\text { Ni de acuerdo } \\
\text { Ni desacuerdo }\end{array}$ & $\begin{array}{c}\text { En } \\
\text { desacuerdo }\end{array}$ & $\begin{array}{c}\text { Muy en } \\
\text { desacuerdo }\end{array}$ \\
\hline Yol & puedo & & & & & \\
\hline 41. & Hablar de mis emociones & & & & & \\
\hline 42. & Expresar afecto & & & & & \\
\hline 43. & Confiar en las personas & & & & & \\
\hline 44 & Superar las dificultades que se me presenten en & & & & & \\
\hline & la vida & & & & & \\
\hline 45. & Desarrollar vínculos afectivos & & & & & \\
\hline 46. & Resolver problemas de manera efectiva & & & & & \\
\hline 47. & Dar mi opinión & & & & & \\
\hline 48. & Buscar ayuda cuando la necesito & & & & & \\
\hline 49. & Apoyar a otros que tienen dificultades & & & & & \\
\hline 50. & Responsabilizarme por lo que hago & & & & & \\
\hline 51. & Ser creativa & & & & & \\
\hline 52. & Comunicarme adecuadamente & & & & & \\
\hline 53. & Aprender de mis aciertos y errores & & & & & \\
\hline 54. & $\begin{array}{l}\text { Colaborar con otros para mejorar la vida en la co- } \\
\text { munidad }\end{array}$ & & & & & \\
\hline 55. & Tomar decisiones & & & & & \\
\hline 56. & Generar estrategias para solucionar mis problemas & & & & & \\
\hline 57. & Fijarme metas realistas & & & & & \\
\hline 58. & Esforzarme por lograr mis objetivos & & & & & \\
\hline 59. & Asumir riesgos & & & & & \\
\hline 60. & Proyectarme al futuro & & & & & \\
\hline
\end{tabular}

